\title{
Osteology of the unenlagiid theropod Neuquenraptor argentinus from the Late Cretaceous of Patagonia
}

Federico Brissón Egli, Alexis M. Aranciaga Rolando, Federico L. Agnolín, and Fernando E. Novas Acta Palaeontologica Polonica 62 (3), 2017: 549-562 doi:https://doi.org/10.4202/app.00348.2017

Neuquenraptor argentinus was described as the first undoubted deinonychosaurian theropod from Gondwana. The only known specimen is represented by a fragmentary skeleton, including a nearly complete foot, coming from Late Cretaceous beds of Neuquén Province, Patagonia, Argentina. Neuquenraptor was later considered as belonging to the Southern Hemisphere paravian clade Unenlagiidae, and proposed as a junior synonym of Unenlagia comahuensis. The aim of the present paper is to include a detailed anatomical description of Neuquenraptor (up to the date only known by a preliminary description). Comparisons with other paravians, especially unenlagiids, resulted in the finding of characters that may be considered as diagnostic of Unenlagiidae (e.g., scar-like fourth trochanter of femur, metatarsal II with tongue-shaped process over the caudal surface of metatarsal III, well-developed convex longitudinal plantar crest of metatarsal IV). Furthermore, comparisons between Neuquenraptor and Unenlagia are carried out with the aim to evaluate the possible synonymy between these taxa. These comparisons indicate that at least two similar-sized unenlagiids were present on the Portezuelo Formation. However, in concordance with previous authors, we are not able to support nor dismiss the possible synonymy between Unenlagia and Neuquenraptor. Additional findings of unenlagiid fossils from the Portezulo Formation will help to clarify the taxonomic status of these taxa.

Key words: Dinosauria, Theropoda, Unenlagiidae, Neuquenraptor, Cretaceous, Argentina, Patagonia.

Federico Brissón Egli [fedebe@gmail.com], Alexis M. Aranciaga

Rolando [mauro.a guido@ hotmail.com] , and Fernando E. Novas [ernovas@yahoo.com.ar

], CONICET and Laboratorio de Anatomía Comparada y Evolución de los

Vertebrados, Museo Argentino de Ciencias Naturales "Bernardino

Rivadavia”, Av. Ángel Gallardo 470 (C1405DJR), Buenos Aires,

Argentina. Federico L. Agnolín [ fedeAgnolín@yahoo.com.ar], CONICET, Laboratorio de Anatomía

Comparada y Evolución de los Vertebrados, Museo Argentino de Ciencias Naturales "Bernardino

Rivadavia”, Av. Ángel Gallardo 470 (C1405DJR), Buenos Aires, Argentina and Fundación de Historia Natural "Félix de Azara", Universidad Maimónides, Hidalgo 775 (C1405BDB), Buenos Aires, Argentina. 
This is an open-access article distributed under the terms of the Creative Commons

Attribution License (for details please see creativecommons.org), which permits unrestricted use, distribution, and reproduction in any medium, provided the original author and source are credited.

Farf Full text $(1,052.2 \mathrm{kB})$ 